\title{
Counter-Cyclical Enforcement of Corporate Law
}

\author{
Amitai Aviram $^{\dagger}$
}

Corporate and securities laws are seen as mitigating corporate fraud by manipulating the incentives of agents: presenting corporate agents with a probability of being caught and punished if they commit fraud. This Article suggests that the same laws also affect corporate fraud in a significant but unappreciated manner, by manipulating the perceptions of the principals: affecting the principals' efforts in monitoring the agents by making them perceive the risk of fraud as more or less likely.

Due to several cognitive biases discussed in this Article, principals misperceive the risk of fraud by their agents in a cyclical manner: they underestimate the likelihood of fraud during booms and overestimate it following busts. As a result, they insufficiently police the agents during booms and excessively do so during busts.

Conspicuous law enforcement triggers cognitive biases that could be thoughtfully used to counter the public's cyclical bias. But political pressures that prosecutors face, as well as their failure to consider law enforcement's effect on principals' perceptions, result in enforcement that is itself cyclical and may exacerbate the biased perception of the risk of fraud.

Monetary policy is analogous in requiring counter-cyclical government intervention, and central banks have successfully stepped up to the task despite facing similar pressure not to intervene counter-cyclically. This Article concludes by examining whether institutional safeguards that free central banks to operate counter-cyclically can be adapted to the context of corporate fraud.

\footnotetext{
† Associate Professor, University of Illinois College of Law. I am grateful for very helpful comments from William Black, Ehud Brosh, Eric Claeys, Rajib Doogar, Lee Fennel, Mitu Gulati, Chris Guthrie, Richard Kaplan, Donald Langevoort, Leandra Lederman, James Lindgren, Richard McAdams, Brett McDonnell, Geoffrey Miller, Gregory Mitchell, Scott Moss, Jonathan Nash, Ed Rock, Jacqueline Ross, Tom Ulen, participants at the Midwest Law \& Economics Association annual meeting, law faculty workshops at Bar-Ilan University, University of Illino1s, Indiana University at Bloomington and Washington University, the Colloquium on Market Institutions and Economic Processes at New York University Department of Economics, the Law and Society Association annual meeting, and the editors of the Yale Journal on Regulation. I also wish to thank Patty Liu and John Sholar for their diligent research assistance.
} 
Introduction.

I. Cyclical Patterns in Fraud Perception and Anti-Fraud Law

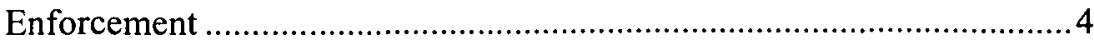

A. Cyclical Biases in Perceiving the Risk of Fraud ...............................

B. Cyclical Trends in Anti-Fraud Law Enforcement........................... 11

C. Explaining the Cyclical Trends: Bias Arbitrage by Law

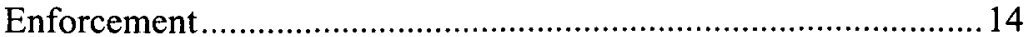

II. Optimal Anti-Fraud Law Enforcement Policies.................................. 18

A. Conspicuous Law Enforcement and Social Welfare......................... 18

B. The Effect of Conspicuous Law Enforcement on Risk

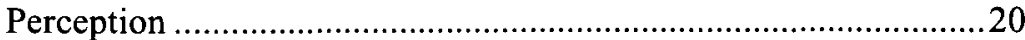

C. Optimal Enforcement When Enforcement Reduces Perceived

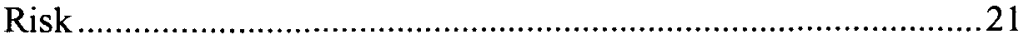

D. Optimal Enforcement When Enforcement Increases Perceived

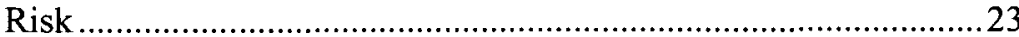

III. Overcoming Impediments to Counter-Cyclical Enforcement ................25

A. Lessons from (Counter-Cyclical) Monetary Policy .........................25

B. Institutional Designs that Facilitate Optimal Enforcement ..............27

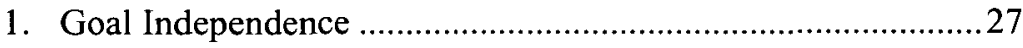

2. Instrument Independence ......................................................30

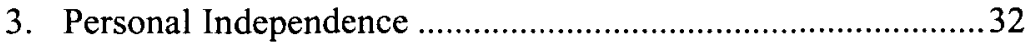

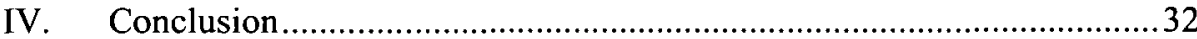

Introduction

Economic activity waxes and wanes in a cyclical pattern known as a business cycle. ${ }^{1}$ Central banks such as the U.S. Federal Reserve Bank mitigate economic shocks by acting counter-cyclically in ways that slow down a booming economy and boost a flagging economy. ${ }^{2}$ This counter-cyclical monetary policy affects economic activity not only through its objective effect on the supply of money, but also through its impact on the public's expectations of the economy's future. ${ }^{3}$

1 To be more precise, business cycles represent fluctuations in the economy's long-term growth path, rather than being the growth path itself. Robert J. Hodnck \& Edward C. Prescott, Postwar U.S. Business Cycles. An Empirical Investigation, 29 J. MONEY, CREDIT \& BANKING 1 (1997) ("[A]ggregate economic variables in capitalist economies experience repeated fluctuations about their long-term growth paths."). On the development of business cycle theory see, for example, Robert E. Lucas, Jr., Methods and Problems in Business Cycle Theory, 12 J. MONEY, CredIT \& BANKING 696 (1980).

2 Board of Governors of the Federal Reserve System, The federal Reserve SYSTEM: PURPOSES \& FUNCTIONS 15, 16 (9th ed. 2005), http://www.federalreserve.gov/pf/pdf/ pf_complete.pdf.

3 Anthony M. Santomero, President, Fed. Reserve Bank of Phila., Address, Great Expectations: Monetary Policy in Today's Economy (Jan. 10, 2002), available at 
Like monetary policy, the conspicuous enforcement of the branches of securities and corporate law that address corporate fraud ("law enforcement") ${ }^{4}$ impacts the public's expectations (or, more precisely, the public's risk perception regarding fraud). ${ }^{5}$ This effect on risk perception impacts the degree to which the public self-polices against fraud, the degree to which the public avoids activities that are susceptible to fraud, and the degree to which the public influences government to increase regulation that addresses fraud.

The effect of conspicuous law enforcement on potential victims' risk perceptions is largely neglected in the literature, which focuses on the potential perpetrators (rather than the potential victims) and on law's manipulation of incentives that results in deterrence (rather than manipulation of risk perception that affects the amount of self-policing). ${ }^{6}$

In this Article, I explore the policy implications of the effect of law enforcement on risk perception, and ultimately the impact on social welfare. Under certain circumstances discussed below, social welfare would benefit from counter-cyclical patterns of law enforcement. ${ }^{7}$ This conclusion runs contrary to actual enforcement patterns, which tend to be cyclical. ${ }^{8}$

This Article challenges the extant literature on optimal sanctions, which views enforcement policy as a tradeoff between the benefits of deterrence and the costs of enforcement, by adding a third consideration: the costs or benefits of enforcement's effect on the public's risk perceptions. This Article also introduces into the purely microeconomic extant analysis of optimal sanctions a macroeconomic consideration: the cyclical fluctuation in perception of fraud, which tracks the business cycle and significantly impacts the effect law enforcement has on social welfare.

Part I examines what appear to be cyclical patterns in the public's perception of the risk of fraud and in the enforcement of anti-fraud laws: the risk of fraud seems greater, and the enforcement of anti-fraud laws increases, after a slump in the business cycle as compared to during the boom segment of the cycle. This explains why it is likely that cyclical misperceptions of fraud

http:/www.philadelphiafed.org/publicaffairs/speeches/santomero/2002/01-10-02_natl-economists-club. cfm.

4 This Article focuses on conspicuous law enforcement in the context of mitigating corporate fraud. However, the same analysis is applicable in many other contexts in which law is enforced conspicuously.

5 See Amitai Avıram, Bias Arbitrage, 64 WASH. \& LEE L. REv. 789 (2007) [hereinafter Aviram, Bias Arbutrage]; Amital Aviram, The Placebo Effect of Law: Law's Role in Manipulating Perceptions, 75 GeO. WASH. L. REV. 54 (2006).

6 See, e.g, Vincent Di Lorenzo, Does the Law Encourage Unethical Conduct in the Securities Industry?, 11 FORDHAM J. CORP. \& FiN. L. 765, 765 (2006); Mary Kreiner Ramirez, The Science Fiction of Corporate Criminal Liability: Containing the Machine Through the Corporate Death Penalty, 47 ARIZ. L. REv. 933, 934 (2006); Betty Joan Thurber, A Behavioral Science Analysts of Sarbanes-Oxley's Certification Requirements- the Right Kind of Deterrence?, 7 TENN. J. BUS. L. 123 (2005).

7 See infra Part II.

8 See infra Section I.B. 
would lead to a cyclical pattern of law enforcement, as law enforcers engage in strategic behavior called "bias arbitrage.",

Part II incorporates the cyclical pattern of risk perception into the literature on optimal law enforcement. Conspicuous law enforcement sends a dual-faceted signal to the public of both the existence of fraud and of fraud being addressed by the law. Depending on circumstances discussed in this Part, conspicuous law enforcement can either increase or decrease risk perception. This Part goes on to analyze, under each of these scenarios, the effects of conspicuous law enforcement on social welfare (and therefore optimal enforcement policy). Under some circumstances, a social welfare-maximizing law enforcement policy would need to be counter-cyclical, responding to and mitigating the cyclical pattern of risk perception.

Part III examines how law enforcement can break from the mostly cyclical enforcement pattern described in Part I to allow, when beneficial, the facilitation of a counter-cyclical enforcement pattern. I examine areas in which counter-cyclical policy is used-primarily in executing monetary policy-to learn what features increase a law enforcer's ability to maintain a countercyclical policy in the face of opposing political pressure. I then consider how these features may be adopted in the context of anti-fraud law enforcement.

\section{Cyclical Patterns in Fraud Perception and Anti-Fraud Law Enforcement}

The common narrative on the impact of corporate law on fraud is an evolutionary one: agents have an incentive to defraud the principal, ${ }^{10}$ but this incentive is kept in check by law. To escape law's constraints, agents find and exploit loopholes in the law. In response, the law is amended to close the loopholes. ${ }^{11}$ Thus, the substance of the law evolves, while its enforcement is held constant, at the highest level possible under budgetary constraints.

While this narrative has some merit and influences the behavior of law enforcers, it does not describe the only way-or perhaps even the most significant way-in which corporate law affects fraud. Fraud is kept in check not only by the deterrence of government sanctions, but also by the principals' monitoring of their agents. ${ }^{12}$ The amount of such monitoring depends on the

9 Bias arbitrage will be explained in Section I.C and is explained in greater detail in Aviram, Bias Arbitrage, supra note 5.

10 Robert Prentice, Whither Securities Regulation? Some Behavioral Observations Regarding Proposals for Its Future, 51 DUKE L.J. 1397, 1423-25 (2002).

11 See, e.g., Blue Chip Stamps v. Manor Drug Stores, 421 U.S. 723, 765-66 (1975) (Blackmun, J., dissenting) (quoting SEC Release No. 3230 (May 21, 1942)) ("The new rule closes a loophole in the protections against fraud adminıstered by the Commission by prohibiting individuals or companies from buying securit1es if they engage in fraud in their purchase."); Joel Seligman, The Reformulation of Federal Securities Law Concerning Nonpublic Information, 73 GEO. L.J 1083, 108889 (1985).

12 In the context of corporate fraud, the agents are the corporate insiders (directors and officers) who are potential perpetrators of fraud, while the principals are the parties who are potential victims of such fraud (typically the shareholders). Not all principals have the same abilities to respond to 
principals' perception of the likelihood of fraud. Such perception is susceptible to cognitive biases, and, I argue here, is likely to be cyclical: principals perceive fraud as less likely (and reduce policing) during booms, and overestimate the likelihood of fraud (and increase policing) following busts.

This Article suggests a complementary narrative that is cyclical rather than evolutionary, focusing on the enforcement rather than the substance of corporate and securities laws. The role of law in fighting fraud is not limited to deterring fraud and incapacitating perpetrators, but may extend to de-biasing principals' perceptions on fraud and therefore facilitating more effective private responses to fraud. Even if prosecutors choose not to extend law's role, law enforcement manipulates principals' perceptions, thus affecting principals' selfpolicing. This, in turn, affects the prevalence of fraud. This effect is separate from, and may be in the opposite direction of, law enforcement's effect on fraud caused by its manipulation of agents' incentives.

For law's effects on risk perception to be considered in developing an optimal enforcement policy, these effects must be predictable; i.e., follow a certain pattern or patterns. Below I will argue why the risk perception of corporate fraud follows a cyclical pattern that corresponds to the performance of the stock market (and, indirectly, to business cycles). Following that, I will present evidence that law enforcement efforts against corporate fraud follow the same pattern. Then I will tie these two cyclical patterns together by explaining why cyclical shifts in risk perception would likely result in cyclical enforcement of the law.

\section{A. Cyclical Biases in Perceiving the Risk of Fraud}

Stock markets are volatile, but rather than shifting randomly their price fluctuations tend to have trends that rotate cyclically: an upward trend during a "bull market," followed by a downward trend during a "bear market." These trends are shaped by numerous factors, from monetary policies to housing prices to business cycles. Yet downward trends are perceived very frequently to involve fraud and to be caused by fraud. ${ }^{13}$ Thus, while there were a great number of causes for the downward trend in U.S. stock prices between early 2000 and late 2002, this slump became associated with scandals in Enron, WorldCom, Tyco and others.

fraud, but all principals can respond in some way to fraud. A dominant shareholder may monitor the agents directly, replace them, or force institutional changes in the corporation that reduce the agents' discretion and increase oversight. A shareholder with a smaller stake may not be able to effect these changes, but could reduce or avoid investment in corporations she perceives to be susceptible to a high risk of fraud.

13 See, e.g., Charles P. Kindleberger, Manias, Panics, and Crashes: A History of FINANCIAL CRISES 73-90 (4th ed. 2000) (providing many examples of fraud accompanying economic panics); Tony Jackson, Investors Should Be Wary of Backlash over Top People 's Pay, FIN. TIMES, Jan. 3,2007 , at 34 ("The fact that something goes in cycles, after all, does not mean it can be shrugged off. Corporate crime is cyclical too."). 
The prevalence of fraud as the perceived cause of a stock market slump should not be surprising. Most causes of stock price fluctuation are complex, abstract and unintuitive (e.g., explaining why an increase in bank reserve requirements or in the federal funds rate causes a drop in stock prices). Fraudinsiders stealing the value that the stock has lost-is intuitive and vivid. ${ }^{14}$ Many people exhibit a vividness bias that causes them to place more weight on concrete, emotionally interesting information than on more probative abstract data. ${ }^{15}$ A causal explanation that is more concrete, vivid and easier to understand is more likely to be perceived as the correct causal explanation.

Independent of its vividness, fraud is attractive as the causal explanation for market slumps because it provides a perpetrator and a motive, both of which are missing in complex economic causes. ${ }^{16}$ For all of the above reasons, fraud is an attractive explanation for stock market slumps.

Once fraud is deemed a likely cause of the slump, other causes are less likely to be considered. People may tend to prefer a single explanatory cause to an event over multiple causes. ${ }^{17}$ In a phenomenon known by psychologists as "discounting," identifying a potential cause as more likely has the effect of making all other potential causes seem less likely. ${ }^{18}$ For example, a lawn may be wet because it rained, or because the sprinklers turned on. An individual who is told that the sprinklers turned on may consider it less likely that it rained, even though these causes are not mutually exclusive. ${ }^{19}$

Similarly, once fraud seems a likely cause for a market slump, discounting may cause people to ignore other causes of the slump, even though stock prices are affected by a multitude of forces. Indeed, the public may continue to view fraud as the cause of market slumps, even in the face of evidence casting doubt as to the fraud's prevalence, as long as the fraud seems a more likely cause of

14 This portrayal of fraud as theft is simplistic, of course. Some instances of securities fraud are forms of embezzlement. See, e g., Hollinger v. Titan Capital Corp., 914 F.2d 1564 (9th Cir. 1990); State v. Ross, 715 P.2d 471 (N.M. Ct. App. 1986); State v. Swift, 496 N.W.2d 713 (Wis. Ct. App. 1993). But many instances of securities fraud involve disclosure fallures or misstatements that are not related to embezzlement. For example, a CEO who knowingly presents an excessively optımistic assessment of her company in order to buy time for it to improve its performance. E.g., Goplen v. 51 job, Inc. $453 \mathrm{~F}$. Supp. 2d 759, 764-65 (S.D.N.Y. 2006); In re New York Cmty. Bankcorp, Inc., 448 F. Supp. 2d 466 (E.D.N.Y. 2006); In re Spear, 399 F. Supp. 2d 1350 (S.D. Fla. 2005).

15 Harry S. Gerla, The "Reasonableness" Standard in the Law of Negligence: Can Abstract Values Receive Their Due?, 15 U. DAYTON L. REV. 199, 210 (1990) (citing RICHARD NISBETT \& LEE Ross, HUMAN INFERENCE: STRATEGIES AND SHORTCOMINGS OF SOCIAL JUDGMENT 55-61 (1980))

16 Providing a perpetrator or a motive makes the cause seem more plausible. See, e.g., Margaret C. Campell, Perceptions of Price Unfairness: Antecedents and Consequences, $36 \mathrm{~J}$. MARKETING RES. 187, 197 (1999) (finding that an "inferred motive of the firm in setting a price is a factor in consumers' perceptions of price unfaimess").

17 See, e.g, Hillel J. Einhorn \& Robin M. Hogarth, Judging Probable Cause, 99 PSYCHOL. Bull. 3 (1986); Harold H. Kelley, The Processes of Causal Attribution, 28 AM. PsyCHOLOGIST 107 (1973).

18 See, e.g., Daniel M. Oppenheimer, Spontaneous Discounting of Avalabllity in Frequency Judgment Tasks, 15 PSYCHOL. SCI. 100, 100 (2004).

19 See id. 
the market slump than any of the other less vivid and understandable explanations. $^{20}$

Other cognitive biases may play a role in exacerbating the perception of fraud during downwards trends and underestimating the risk during upwards trends. Self-serving bias is the tendency, when evidence as to the cause of an outcome is ambiguous, to attribute one's actions to positive outcomes and attribute other causes to negative outcomes. ${ }^{21}$ The return on an investment in a company is an outcome that has ambiguous causes: it is perceived to depend on skill in picking the right investment (by predicting future events or trends, and their impact on potential investments), though unpredictable events can also affect the company. ${ }^{22}$ When the investment does well (which is more likely to occur during upwards market trends), self-serving bias causes a person to attribute the success of her investment to her skills. But when the investment does poorly, self-serving bias causes an individual to resist inferring that she has poor investment skills. Instead, an individual seeks another cause for the poor performance-preferably one that would not have been reasonably predictable and therefore does not reflect on the investor's skills. Fraud is an appealing explanation for the investment's decline because fraud is specifically prohibited (thus, perhaps, unexpected) and the ability to predict susceptibility to fraud is less indicative of one's investment skills than the ability to predict, say, economic trends that impact the company. Since securities offerings are policed by the government, investors may view government as responsible for anticipating and preventing fraud. ${ }^{23}$ Failure to anticipate fraud, therefore, may reflect badly on the government, but it does not reflect as badly on the individual's investment skills. ${ }^{24}$ Thus, a person affected by self-serving bias is

20 Hillel Einhorn and Robin Hogarth call this form of inference the "replacement" mode of inference (as opposed to the "disconfirmation" mode, which rejects a causal explanation if faced with evidence to the contrary, even if no other explanation is better supported by evidence):

The replacement view is consistent with the Kuhnian notion that theories in science are not discarded, despite evidence to the contrary, if they are not replaced by better alternatives.... Indeed, the replacement view is equally strong in everyday inference. A useful analogy might be the following: How many people would read detective stories if the author only revealed who did not do it?

Einhom \& Hogarth, supra note 17, at 15 (citng ThOMAS S. KUHN, THE STRUCTURE OF SCIENTIFIC REVOLUTIONS (1962)).

21 See Amy H. Mezulis et al., Is There a Universal Positivity Bias in Attributions? A MetaAnalytic Review of Individual, Developmental, and Cultural Differences in the Self-Serving Attributional Bias, 130 PSYCHOL. BULL. 711,738 (2004).

22 Michael L. Hartzmark, Luck Versus Forecast Ability: Determinants of Trader Performance in Futures Market, 64 J. Bus. 49 (1991) (finding support for the "luck hypothesis" through analysis of futures traders' returns).

23 Jon Klick and Greg Mitchell make a related point in a broader context, claiming that paternalism reduces incentives of individuals to de-bias themselves and learn from failures. See Jonathan Klick \& Gregory Mitchell, Government Regulation of Irrationality: Moral and Cognttive Hazards, 90 MINN. L. REV. 1620, 1627-41 (2006).

24 In contrast, govemment makes no guarantees as to the quality of securities, however, so failing to predict that interest rates will rise and reduce a company's profitability would be a demerit to the investor, not government. 
more likely to perceive fraud as the cause for a decline in her investment, leading to a heightened perception of fraud when markets (and therefore most investments) decline and to a reduced perception of fraud when markets surge.

Availability bias-the tendency to "assess the frequency of a class or the probability of an event by the ease with which instances or occurrence can be brought to mind"25 - also contributes to overestimating the risk of fraud when markets decline and underestimating the risk when markets rise. Availability bias causes people who are exposed to a small number of noticeable events to overestimate the likelihood of such events. For example, several reports of deaths from Severe Acute Respiratory Syndrome (SARS) in Canada resulted in Canadians perceiving the probability that they would suffer serious harm or death from SARS as $7.43 \%$ (and perceived an even higher probability$8.94 \%$ - to others of their age and geographic region), while the actual probability of contracting SARS was $0.0008 \%$ (and the probability of dying from SARS was $0.0002 \%)$. ${ }^{26}$ Similarly, the murder of ten people by snipers in the Washington, D.C. area during the fall of 2002 caused millions of people to significantly change their lifestyles to avoid exposure to this risk, a risk that one scholar estimated to be

smaller than the risk of death from drinking thirty diet sodas with saccharin, from driving one hundred miles, from smoking two cigarettes, from ten airline trips, from living in a home with a smoker for two weeks, from living in Denver rather than Philadelphia for forty days, and from eating thirty-five slices of fresh bread. $^{27}$

How do economic cycles trigger an availability bias? Downturns in the economic cycle expose existing fraud because, as explained above, investors see fraud as a probable explanation for the decline in stock price. They view fraud as more probable and increase efforts to uncover it, thus increasing the probability that hidden fraud would be detected. Furthermore, during economic downturns, many companies' cash flows diminish, making some types of fraud (such as embezzlement) harder to conceal. ${ }^{28}$ As a result, downturns increase the probability that an ongoing fraud in a company will be exposed. ${ }^{29}$

25 Amos Tversky \& Daniel Kahneman, Judgment Under Uncertainty Heuristıcs and Biases, 185 SCIENCE 1124,1127 (1974).

26 Neal R. Feigenson et al., Perceptions of Terrorism and Disease Risks: $A$ Cross-National Comparison, 69 Mo. L. REV. 991, 996-99 (2004).

27 Cass R. Sunstein, What's Available? Social Influences and Behavioral Economics, $97 \mathrm{NW.}$ U. L. REV. 1295, 1297 n.13 (2003) ("The risk of living in Denver comes from slightly elevated radiation levels; the risk from eating fresh bread comes from formaldehyde.").

28 Admittedly, not all types of fraud are concealed by cash flow. Some types of fraud, such as providing false positive information about a company, may be more likely to occur when the company is doing poorly than when it is doing well.

29 While the SEC and industry regulators attempt to detect corporate fraud, the role of actors that lack an explicit mandate to discover fraud, such as the media or employees, is often greater. See I.J. Alexander Dyck et al., Who Blows the Whistle on Corporate Fraud? (European Corp. Governance Inst. Fin., Working Paper No. 156, 2007), available at http://papers ssrn.com/sol3/papers.cfm? abstract_id=959410 (finding that between 1996 and the enactment of the Sarbanes-Oxley Act, only 35\% of corporate fraud cases in the study were discovered by actors with explicit mandates to do so, and 
Economic downturns affect many companies at the same time, so the likelihood of exposing ongoing fraud in each of them increases at the same time. The resulting discovery of fraud in several companies in rapid succession is likely to trigger an availability bias that would cause individuals to overestimate the prevalence of fraud, just as reports of several deaths from SARS within a short period of time created a perception of a catastrophic SARS epidemic.

This misperception is likely to be exacerbated by social amplification-a tendency to perceive a risk as greater if it concerns others as well. ${ }^{30}$ Social amplification is particularly galvanized by mass media: very few of the readers of this Article have personally seen a person die from SARS, but nearly all readers have heard on the news of people dying from SARS. Each individual's risk perception is affected by the availability of knowledge of SARS's victims, but the risk perception is further heightened by discovering that others are also concerned about SARS, even though the concern by others has been triggered by the same report. Because economic downturns affect many companies at once, there are large numbers of people who suffer loss of their investments and are, therefore, concerned about fraud. An individual's concern about fraud is then amplified by concerns of her colleagues. This exacerbates her perception of the risk of fraud beyond the risk she would have perceived had fewer companies suffered a slump, since fewer colleagues would share her concern about fraud.

Thus far we addressed the impact of an economic downturn on individuals' perception of fraud. But economic downturns also affect individuals' incentives to investigate potential instances of corporate fraud and to attempt to manipulate others' perceptions of fraud. Because the mind tends to prefer causal explanations that conform with the observed result, ${ }^{31}$ it may be easier to persuade a judge or jury, in the face of declining stock prices, that fraud (which should reduce stock prices) took place.

Furthermore, if fraud is established, proof of the financial loss that resulted from the fraud tends to be easier when stock price declined as compared to when it rose. As discussed earlier, ${ }^{32}$ the phenomenon of discounting causes people to view potential causes to an event as less likely if another potential cause seems more likely. Thus, if fraud has been established,

from the enactment of Sarbanes-Oxley to 2004 these actors accounted for only slightly more than $50 \%$ of the cases).

30 See Cass R. Sunstein, The Laws of Fear, 115 HARv. L. REv. 1119, 1130-37 (2002) (discussing social amplification and the mechanisms that shape it).

31 This is a variation of confirmation bias. See infra note 35. When stock prices rise, people are less likely to expect events that would cause prices to decline, such as fraud, and are therefore more likely to discount ambiguous evidence that could indicate fraud.

32 See supra notes 17-20 and accompanying text. 
judges and juries are more likely to overestimate the portion of the price decline attributable to the fraud. ${ }^{33}$

Just as these cognitive biases enhance the perception of fraud when stock markets decline, they attenuate the perception of fraud when markets rise. Attribution discounting ${ }^{34}$ and confirmation bias ${ }^{35}$ make the perception of fraud in a rising market less likely, because fraud would explain a market decline, not a market rise. A simple, single-cause explanation for the market rise (e.g., favorable market conditions) tends to be more appealing than a more complex and nuanced assessment in which positive explanations are encumbered-but not completely offset - by fraud. In addition, self-serving bias in a rising market favors the adoption of a causal explanation connecting the rising stock prices to the investor's skill in picking the investment, rather than to fraudulent optimistic misrepresentations. Overconfidence in one's investing skills may also make one overestimate her ability to detect potential fraud (and thus reduce the amount she invests in monitoring for fraud).

As the rising economic tide lifts most ships, more companies are able to hide fraud (e.g., in cases of embezzlement) and fewer companies need to resort to fraud (e.g., in cases of over-optimistic misrepresentations aimed to buy the company time to recover from a downturn). In addition, rising markets reduce the incentive of even non-biased potential plaintiffs and lawyers to investigate possible fraud, because of increased uncertainty in proving the occurrence of fraud and the loss caused by it. Thus, instances of exposed fraud are fewer and less frequent, reducing availability. When the stock price rises, discounting and confirmation bias may become hurdles to the plaintiff, causing juries and judges to underestimate the impact of an alleged event (fraud) that should reduce stock prices. As a result, litigation that alleges fraud becomes riskier and more costly for the plaintiff when stock prices rise. This reduces the incentives for lawyers and plaintiffs to incur expenses in investigating the existence of fraud, even if they overcame cognitive biases and correctly estimated the risk

33 I am not claiming that the legal standard for assessing the loss is biased. Under Dura Pharmaceuticals Inc. v. Broudo, 544 U.S. 336 (2005), the mere drop in the price of a share following the exposure of a misrepresentation is insufficient to prove loss causation in a securities fraud action under SEC Rule 10b-5 because "that lower price may reflect, not the earlier misrepresentation, but changed economic circumstances, changed investor expectations, new industry-specific or firm-specific facts, conditions, or other events, which taken separately or together account for some or all of that lower price." Dura, 544 U.S. at 343.

However, judges and juries are likely to exhibit cognitive biases in determining whether a loss is attributed to fraud. See Chris Guthrie et al., Inside the Judicial Mind, 86 CORNELL L. REV. 777 (2001) (suggesting that judges are susceptible to several cognitive biases). Thus, the unbiased legal standard may be applied in a manner that is biased in favor of attributing a larger fraud-related loss when stock markets decline than when they rise.

34 See supra notes 17-20 and accompanying text.

35 Confirmation bias is "the tendency to seek out only confirmatory evidence in hypothesis testing, even when the presence or absence of disconfirming evidence would be more useful." Jeffrey J. Rachlınski, Cognitlve Errors, Individual Differences, and Paternalism, 73 U. CHI. L. REV. 207, 217 (2006). 
of fraud. ${ }^{36}$ During such times, corporate fraud less frequently enters public discourse, resulting in social attenuation of the risk (the inverse of social amplification)_reducing one's risk perception when the risk seems not to concern others.

The analysis above suggests that fraud is likely to be overestimated during and immediately following market slumps, and is likely to be underestimated during market booms. ${ }^{37}$ Such misperceptions affect the amount of effort investors place in self-policing, ${ }^{38}$ the pressure they place on government to intervene to protect them from fraud, and the degree to which they altogether avoid investing in venues susceptible to fraud. Government responds to the public's risk perceptions by enacting and enforcing laws in ways that either correct the public's misperceptions or exacerbate them and thus either improve social welfare (by reducing the biases and therefore shifting individuals' selfpolicing, political pressure, and risk avoidance closer to the optimal level) or reduce it (by exacerbating the biases). Part II of this Article will consider when conspicuous law enforcement ${ }^{39}$ improves social welfare and when it does not. Before engaging in this analysis, the remainder of Part I will examine how antifraud law enforcement is deployed in practice: a cyclical pattern that mimics the cyclical misperception of the public in perceiving the bias.

\section{B. Cyclical Trends in Anti-Fraud Law Enforcement}

Scholars have long observed the cyclical pattern of creating and enforcing laws regarding corporate fraud: a wave of regulation in response to a stock

36 See, eg., The Lex Column, FIN. TIMES, Jan. 4, 2007, at 16 ("Investors cut company managers more slack when share prices are going up. That partly explains a sharp decline in the number of US securities class action lawsuits in 2006 compared with 2005. This is not just psychological. If a company's valuation is rising, its shareholders have no financial loss on which to hang litigation, whatever managers might be up to.").

37 The analysis above was theoretical: it applied to the context of corporate fraud cognitive biases that were empirically tested in other contexts. It is difficult to conduct a direct empirical examination of whether the public misperceives corporate fraud. Even if perceptions could be accurately measured, the researcher would need to have data on the actual incidence of fraud in order to determıne whether a given perception was correct. However, any data on the actual incidence of fraud is likely to be tied to enforcement efforts-more reported fraud may be the result of more vigorous law enforcement rather than an increase in the occurrence of fraud. Since this Article argues that law enforcement affects risk perception, it cannot use a proxy for actual fraud that is dependent on the amount of law enforcement

The analysis above is also not universal (i.e., does not apply to every individual, all of the tıme): while the cyclical misperceptions of fraud affect public discourse, political responses, and investors' actions, individuals differ in their susceptibility to cognitive biases See Chr1s Guthrie \& Jeffrey J. Rachlinski, Insurers, Illusions of Judgment \& Litigation, 59 VAND. L. REV. 2017 (2006) (suggesting that insurance claim adjusters are less susceptible to some cognitive biases than the general population); Rachlinski, supra note 35 (discussing evidence on individual differences in susceptibility to cognitive biases).

38 There would be insufficient self-policing efforts, political pressure and activity avoidance when the public underestimates the risk. Conversely, there would be excessive self-policing efforts, political pressure and activity avoidance when they overestimate it.

39 For example, law enforcement that is observed by the public and affects the public's perceptions. 
market slump, followed by a plateau and a decline in regulation until the occurrence of the next slump. In his essay What Causes New Securities Regulation? 300 Years of Evidence, Stuart Banner argues that securities regulation evolved not in response to technological changes, but simply in response to the fact that the market crashed:

In the past three hundred years, [arguments as to the inefficiency of speculation] have periodically persuaded governments to regulate the market so as to restrict trading. Such episodes of regulation have been closely linked to price declines. If one wants to know what future event would be most likely to persuade governments that [the view that speculation is inefficient] is right, the answer is not new developments in information technology. The answer is a crash.

Larry Ribstein describes the cycle in greater detail:

A boom encourages unwarranted trust in markets, leading to the speculative frenzy of a bubble and then to the inevitable bust. The bust, in turn, leads first to the disclosure of fraud and then to the mirror image of the bubble-a kind of speculative frenzy in regulation. ${ }^{41}$

This cyclical pattern seems to apply not only to the enactment of new laws, but also to the enforcement of existing ones. Consider the graph below. The solid line represents, as a proxy for the trend in enforcement, the change (compared to the previous year) in the number of enforcement actions initiated by the SEC in each of the fiscal years 1995-2006. ${ }^{42}$ The dashed line represents, as a proxy for the trend of stock prices, the change in the S\&P 500 index in the

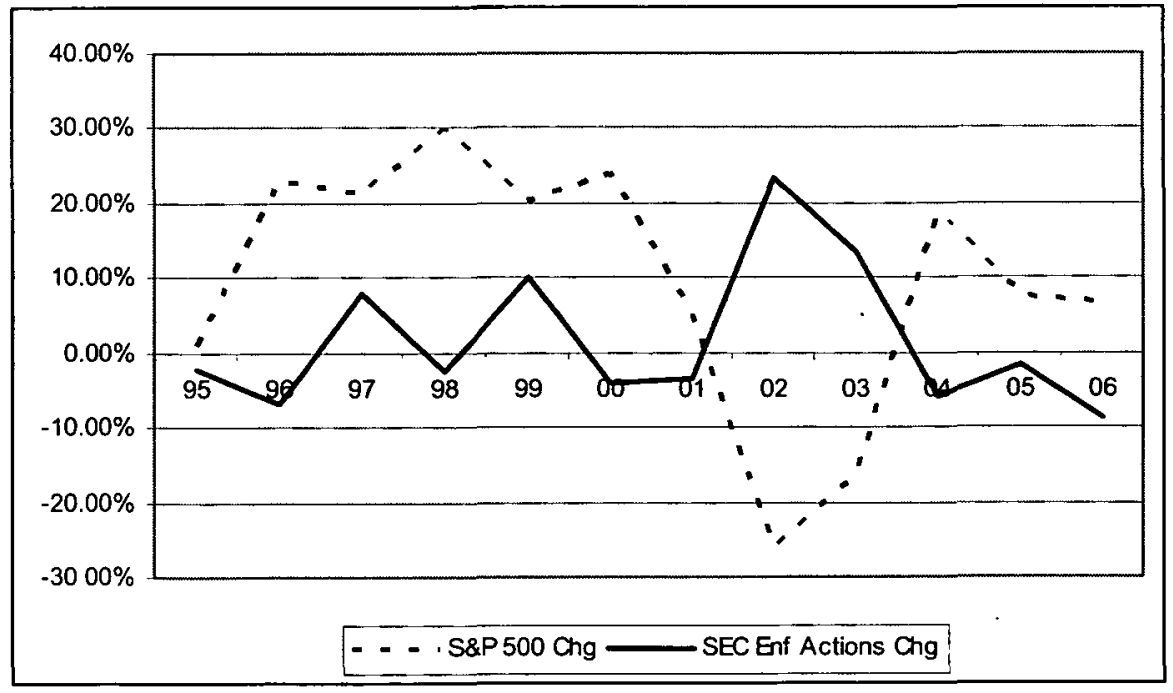

40 Stuart Banner, What Causes New Securtties Regulation? 300 Years of Evidence, 75 WASH. U. L.Q. 849, 855 (1997).

41 Larry E. Ribstein, Bubble Laws, 40 Hous. L. REv. 77, 78 (2003).

42. SEC. \& EXCH. COMM'N, ANNUAL REPORTS 1994-2006, http://www.sec.gov/about/ annrep.shtml (containing tables in each report's appendix with enforcement data for the fiscal year). The U.S. Government fiscal year runs from October 1 to the following year's September 30. 
year preceding the first day of the fiscal year. ${ }^{43}$ One can observe a tendency of the two proxies to move in opposite directions-significant increases in enforcement actions when the market index declines (or significantly slows its upward trend), and decreases (or very mild increases) in enforcement actions when the market index rises significantly. ${ }^{44}$

Several scholars have been critical of this cyclical pattern, mostly for two reasons: (a) its focus on government-mandated solutions to fraud, which preempt and preclude market-based solutions; ${ }^{45}$ and (b) the tendency to prefer speed (of legislation or enforcement) to substance. ${ }^{46}$ Roberta Romano cautions:

[L]egislating in the immediate aftermath of a public scandal or crisis is a formula for poor public policymaking (at least in the context of financial market regulation). The high salience of events forestalls a careful and balanced consideration of the issues, providing a window for action by the betterpositioned, not the better-informed, policy entrepreneurs. This is a particular concern because legislation drafted in a perceived state of emergency can be difficult to undo. ${ }^{47}$

This cyclical view of anti-fraud law creation and enforcement is held not only by scholars who advocate less mandatory government regulation of fraud, but also by some who call for more such regulation. Erik Gerding also describes the cyclical pattern of increased enforcement following busts and reduced enforcement during booms, ${ }^{48}$ but focuses on the empty half of the regulation glass. Disagreeing with Romano's observation that "bubble laws"

43 For example, the figure for fiscal year 2005, which begins on Oct. 12004 , would be the change in the S\&P 500 index between Oct 1, 2003 and Oct. 1, 2004. This figure indicates the stock market trend observed by regulators at the beginning of the fiscal year, and therefore affecting the enforcement efforts in the year that follows. S\&P 500 index data was drawn from http://finance.yahoo.com/q/hp?s=\%5EGSPC.

44 This data suggests that the law enforcement shares with law creation the cyclical pattern discussed in the literature. It is not a rigorous empirical analysis of the correlation between market indexes and enforcement actions. Such an examination is outside the scope of this Article.

45 Ribstein, supra note 41 ("Regulators are more likely to react to past market mistakes than to prevent future mistakes. Even worse, post-bust regulators are likely to ignore the benefits of market flexibility and, therefore, to impede the risk-taking and innovation that will bring the next boom."); Roberta Romano, The Sarbanes-Oxley Act and the Making of Quack Corporate Governance, 114 YALE L.J. 1521, 1602 (2005) ("The specific policy implıcatıon drawn from this Article's analysis of the scholarly literature and political dynamics is that the mandates should be rescinded, either by transforming them into statutory defaults that apply to firms at their option or by removing them completely and redirecting jurisdictional authority to the states.").

46 Romano, supra note 45 , at $1525-26$ ("[I]t was widely perceived in the media that members of Congress were motivated by reelection concerns when a statute was hurriedly enacted in the summer prior to the midterm elections, after months of languishing in committee, following heightened attention on corporate malfeasance as the WorldCom scandal erupted post-Enron. The suggestion from the media was that the priority of members of Congress was to enact something, with the specific content of less concern and importance."). See also Lynnley Browning, U.S Moves to Restrain Prosecutors, N.Y. TIMES, Dec. 13, 2006, at $\mathrm{Cl}$ (describing a backlash against aggressive prosecutorial tactics by the Department of Justice); Greg Burns, Backlash Against Hardball Tactics, CHI. TRIB, Jan. 14, 2007, at 5-1 (describing a backlash against aggressive prosecutorial tactics by appellate judges).

47 Romano, supra note 45 , at 1602.

48 Erik F. Gerding, The Next Epidemic: Bubbles and the Growth and Decay of Securities Regulation, 38 CONN. L. REV. 393 (2006). 
(as Ribstein calls them) ${ }^{49}$ are difficult to undo, Gerding claims that during market booms the funding of enforcement agencies does not increase in proportion to the increase in market activity, resulting in the enforcement agency being overwhelmed and ineffective. ${ }^{50}$ Thus, while Ribstein, Romano, and others focus on the increase in legislation and enforcement following busts, Gerding points out the de facto decrease in enforcement (though, typically, without formal repeal of the legislation) during booms.

\section{Explaining the Cyclical Trends: Bias Arbitrage by Law Enforcement}

What causes politicians to enact new legislation and enforce laws more vigorously (or, at least, more conspicuously) following a market crash? Romano suggests that politicians are motivated by reelection concerns, and thus prefer a fast response to a good response. ${ }^{51}$

This argument has appeal, but it also has a troubling flaw: if the law is ineffective (or harmful), wouldn't the law's failure be exposed after some time? At first blush, this is not a problem for the politician as long as the law's failure is exposed after elections are held. After all, while a statesman thinks of the next generation, a politician thinks of the next election. ${ }^{52}$

But closer examination suggests that a politician's incentives depend on the election terms. For example, assume that a cynical, purely self-interested politician is six months away from elections and is considering sponsoring a bill that will boost her popularity so that she wins the coming elections, yet she suspects that the law she is enacting will ultimately fail to solve the problem it addresses. Also assume that this failure will only be apparent a year after the law's enactment (i.e., after the elections), and this failure will remain salient for two years (until this issue fades from the memory of the public and is replaced by other concerns). If this politician is a U.S. Senator, hoping to be reelected for a six year term, then she would have an incentive to sponsor the law. If she does not, she may lose the election and stay out of office for six years. If she does sponsor the law, she will be elected and will endure the embarrassment of association with a policy failure for two years. After that time, the debacle will be forgotten, and neither the latter half of her term nor her next bid for reelection will be affected by the law's failure.

Now consider, under the same assumptions, if the politician is not a Senator but a Congresswoman, elected for a two-year term. If she sponsors the bill, she will be elected for office, but then spend her entire term (and her next bid for reelection) under the shadow of the law's failure. If she declines to

49 Ribstem, supra note 41.

50 Gerding, supra note 48 , at $432-37$.

51 See Romano, supra note 45.

52 I am paraphrasing a quote attributed to James Freeman Clarke: "A politician, for example, is a man who thinks of the next election; while the statesman thinks of the next generation." J.F. Clarke, Wanted, A Statesman!, in 2 OLD \& NEW 644 (1870). 
sponsor the bill, and makes public her reservations to it, she may lose the next bid for re-elections against a rival who sponsors or supports the bill, but as the bill's (now the law's) failure becomes apparent, her consistent position against it should reap electoral rewards in the next elections, while her rival will be tainted by the law's failure. Thus, a self-interested but far-sighted Congresswoman would prefer, under our assumptions, not to support the bill despite its short-term benefits in the impending elections.

Ribstein hints at another explanation for the surge in anti-fraud legislation following a market crash, by describing this surge as a "speculative frenzy in regulation" that is the mirror image of the market bubble that preceded it. ${ }^{53}$ Are the politicians who enact the laws simply swept by the same panic that ails the public? Politicians, like all people, are susceptible to cognitive biases. It is quite possible that some such biases, such as the illusion of control, ${ }^{54}$ would affect politicians more severely than their constituents when assessing the likely effect of anti-fraud legislation because the politician has more control over enacting the law and overseeing its enforcement than does the constituent.

But this explanation suffers from the same flaw as the previous one. Not all people are equally susceptible to cognitive biases; ${ }^{55}$ therefore, some politicians will have risk perceptions that are more accurate than their biased constituents. These politicians now face the choice of the Congresswoman in our earlier example: they could cater to biased perceptions, knowing that the ineffectiveness of the law they sponsored will eventually be exposed, possibly hindering them in their next bids for reelection, or they could take an unbiased stance that would harm their short-term prospects but may give them credibility in the long term. Having the option to choose between these alternatives is of value to a politician, because sometimes taking the unbiased position would be in the politician's interest. Because only the bias-resistant politicians ${ }^{56}$ possess this advantage (their biased brethren do not see the feasibility of taking the unbiased position and so cannot pursue this course of action in circumstances in which it would be wise to do so), one expects that through an evolutionary process more surviving politicians will possess these traits and resist biases that relate to the perception of risks in the areas in which they are publicly prominent (e.g., resistance to misperceptions regarding the risk of war in the case of politicians who regularly weigh in on matters of defense or foreign policy).

53 Ribstein, supra note 41 , at 78.

54 The illusion of control, which is closely related to optimism bias, is a pattern of overoptımism regarding events the outcome of which depends partially on the individual's skill and partially on other circumstances. See, e.g., Ellen J. Langer, The Illusion of Control, 32 J. PERSONALITY \& SOC. PSYCHOL. 311 (1975).

55 See Guthrie \& Rachlinski, supra note 37; Rachlinski, supra note 35.

56 By "bias-resistant politicians" I refer to a resistance to the partıcular biases that relate to the risk perception of the subject of contemplated legislation (e.g., the perception of fraud during an economic slump). The same politicians may be susceptible to other biases, but their resistance to this particular bias provides them with a competitive advantage as politicians durng economic slumps. 
Any plausible explanation for the sustainability of the cyclical pattern of legislation and law enforcement must address the ability of politicians to retain their credibility in the long term. I argue that politicians maintain their credibility because they address risks that are misperceived to be greater than they are.

For example, suppose that the probability of insiders committing fraud in a given company is $0.001 \%$ (1-in-100,000), but due to cognitive biases of the type discussed above, ${ }^{57}$ the public perceives the probability to be $1 \%$. An Attorney General ("AG") launches a series of investigations into companies' behavior, followed by much publicized criminal charges and arrests. The AG claims that this initiative will deter potential perpetrators, so that the probability of fraud will decline by $99 \%$. Assume that the initiative, in fact, does not affect the objective probability of fraud at all. ${ }^{58}$

Since prior to the law enforcement initiative the public perceived the probability of fraud to be $1 \%$, the $A G$ 's promise of a $99 \%$ reduction translates into a probability of $0.01 \%$. While some individuals may be skeptical of the AG's claims, they witness with time that the frequency of fraud is closer to the AG's claim of $0.01 \%$ than to their previous perception of $1 \%$ (the actual frequency that they are witnessing is, of course, the objective probability$0.001 \%$ ). This lends credibility to the AG's claims that his actions reduced the fraud. Thus, despite the fact that the AG presented his (objectively ineffective) law enforcement initiative as a stunning success (claiming a $99 \%$ reduction in the probability of fraud), his claim would gain credibility over time, rather than lose it. The key to the AG's success was the choice of the risk his law enforcement initiative addressed: a risk that was vastly overestimated by the public. The greater the gap between the perceived risk and the actual risk (the "perception gap"), ${ }^{59}$ the more credit the AG can claim for his initiative, without losing credibility and without requiring the initiative to have greater objective effects.

\section{See supra Section I.A.}

58 It may seem implausible that a law enforcement initiative would have no effect at all on the objectıve probabılity of fraud. This assumption is not very important for the hypothetical's purposes. Given the large difference between the perceived and actual nsks in our example, changing that assumption to increase the initiative's effect on actual risk would not make a significant difference on the public's perception gap (the difference between the perceived and actual probabilities of fraud). Before the initiative, the perception gap had been $0.999 \%(1 \%-0.001 \%)$. After the initiative, the perception gap is $0.009 \%(0.01 \%-0.001 \%)$, a reduction of about $99.1 \%$ in the perception gap. If, at the other extreme of possible objective effects, the initiatıve magically eliminated the objective threat (by forever deterring all people who would commit fraud) the perception gap would be $0.01 \%(0.01 \%-0 \%)$, a reduction of about $99 \%$ in the perception gap.

59 Donald Langevoort discussed a concept similar to the perception gap, which he called the "expectations gap." See Donald C. Langevoort, Managing the "Expectations Gap" in Investor Protection: The SEC and the Post-Enron Reform Agenda, 48 VILL. L. REV. 1139 (2003). His analysis examined how the SEC's behavior and funding reduces or increases the expectations gap. This Article examines how changes in the perception gap affect individuals' behavior and, through that, social welfare. 
The same analysis would apply to legislators taking credit for new legislation they sponsor. It is this analysis that ties together the two cyclical patterns discussed above: the cyclical pattern of the public's misperception of fraud and the cyclical pattern of the government's enforcement of existing antifraud laws and creation of new laws. As discussed above, the public is likely to underestimate the risk of fraud during a stock market surge and overestimate it during a downturn. Therefore, during downturns the risk of fraud becomes an attractive issue for politicians to address. Because at these times the public's perception of the risk of fraud exceeds the actual risk, politicians are unlikely to lose credibility by "overselling" the effectiveness of initiatives (enacting new laws or conspicuously enforcing existing laws) that purport to reduce fraud. The main constraint they face is not the objective success of their initiative, but competition with each other over credit for the illusory reduction of the risk. ${ }^{60}$

During stock market upturns, the situation reverses. The public may underestimate the risk of fraud. This reduces the credit a politician can claim for her initiative. For example, suppose that during an upturn the actual risk of fraud is $0.1 \%$, but the public perceives the probability as $0.01 \%$. If the $A G$ launched a law enforcement initiative that reduced the probability of fraud by an impressive $90 \%$, he would reduce the actual risk to $0.01 \%$-exactly the risk perceived by the public before the initiative began. If the AG honestly claimed his initiative reduced fraud by $90 \%$, the public would expect the probability to now be $0.001 \%$ - a tenth of the actual probability. Over time, the public will see that the frequency of fraud is closer to the probability they perceived prior to the AG's initiative, causing the politician's claims of the initiative's success to lose credibility. In fact, under the assumptions of our hypothetical, if the AG claimed his initiative had any effect at all on reducing fraud, he would lose credibility over time-despite the fact that his initiative is highly successful in fighting fraud.

Actual perception gaps may be less striking than the ones used in the above examples, but the lessons learned from these examples are true for any perception gap: when the perception gap is positive (perceived risk exceeds actual risk) a politician can credibly claim more credit for her initiative than its actual effects warrant; and when the perception gap is negative (actual risk exceeds perceived risk) a politician loses credibility unless she "undersells" her initiatives and claims less credit than the initiative's actual effects warrant. This makes the risk of fraud an attractive issue to address when it is overestimated by the public (i.e., during downturns) and an unattractive issue to address when it is underestimated by the public (i.e., during upturns). This is precisely the cyclical pattern of enforcement that has been observed. ${ }^{61}$

The strategy I described above consists of identifying perception gaps and taking actions (such as conspicuous law enforcement) that close the gap while

61 See supra Section I.B. 
creating private benefits for the person undertaking the actions. This is a form of arbitrage that I call bias arbitrage. ${ }^{62}$ Compare it to traditional arbitrage, such as in commodities: an arbitrageur identifies a gap between the price of gold in London and its lower price in New York. She buys gold in New York and sells it in London, profiting from the price difference. At the same time, her purchases of gold in New York (and those of other arbitrageurs) raise the price of gold there, while her sales in London (and others') lower the price in London, until the price gap is eliminated and the potential for profit dissipates.

Despite the hostility with which they are treated following market busts, ${ }^{63}$ stock and commodity arbitrageurs (often known as "speculators") are seen by economists as enhancing social welfare by mitigating price gaps, making markets more efficient. ${ }^{64}$ Bias arbitrageurs have analogous effects on social welfare when they reduce perception gaps. When optimal (i.e., welfare maximizing) law enforcement policies are devised, these effects should be considered. I will address the social welfare effects of bias arbitrage, and the resulting effect on optimal anti-fraud law enforcement policies, in the next Part of this Article.

\section{Optimal Anti-Fraud Law Enforcement Policies}

\section{A. Conspicuous Law Enforcement and Social Welfare}

When facing a risk, individuals have the choice of confronting it, inducing someone else (such as government) to confront it, or avoiding activities that expose the individuals to the risk (or a combination of the three responses). In the case of the risk of corporate fraud, individuals may expend resources selfpolicing against fraud, ${ }^{65}$ influence government to intervene through increased public law enforcement or the creation of new and more effective laws, ${ }^{66}$ or avoid investment in financial instruments that would be vulnerable to corporate fraud.

62 See Aviram, Bias Arbitrage, supra note 5.

63 See Banner, supra note 40; Lynn A. Stout, Why the Law Hates Speculators: Regulation and Private Ordering in the Market for OTC Derivatives, 48 DUKE L.J. 701, 739 (1999) (summarizing the "unflattenng perceptions of speculators").

64 Stout, supra note 63, at 737-38 (describing how speculators, under the "information arbitrage" model, "promote[] allocative efficiency").

65 Self-policing does not necessanly mean that the shareholders directly monitor the management themselves, but rather that shareholders take action to mitigate the risk rather than avoiding it or letting government mitigate it. For example, they can create or expand a bureaucracy that monitors management (such as an audit committee or a supervisory board), or they can challenge corporate actions that have a business justification but also make the commission of fraud easier or its detection more difficult.

66 Most individuals do not have significant direct influence on politicians, but may passively influence politicians by creating a demand for policies that address risks they are concerned about, and voting for politicians who champion such policies. Politicians, sensing this demand by their constituents, will respond by adopting policies addressing (or at least purporting to address) the relevant risks. 
Each of these responses has costs, but each also has benefits in the form of reduced vulnerability to harm from fraud. Each response is scalable, rather than binary: one can invest more or invest less in self-policing, political pressure, and in the stock market. An individual balances the mix of responses based on the relative cost and effectiveness of each, spending the marginal dollar (or equivalent sacrifice of utility) on whichever response (self-policing, influencing others, or avoidance) has the greatest marginal effect on reducing the risk.

The magnitude of an individual's response to a risk depends on the individual's perception of the risk. She will incrementally increase each response at her disposal until the marginal cost of the response equals the marginal reduction in the harm the individual perceives from the risk.

While an individual's response to a risk depends on the perceived risk, the optimal response to a risk depends on the actual risk and is the equilibrium point at which the marginal cost of the most efficient response not yet undertaken is equal to the marginal reduction this response causes to the harm from the risk. An individual will respond optimally if she correctly perceives the risk (i.e., her perceived risk is identical to the actual risk)-in other words, when her perception gap is zero. Responses become less efficient as the perception gap grows in either direction. An increase in a perception gap that is positive (i.e., the perceived risk is higher than the actual risk) means that responses are costlier than the harm from the risk they mitigate; an increase in a perception gap that is negative (i.e., the perceived risk is lower than the actual risk) means that the individual foregoes cost-effective responses.

Any effect conspicuous law enforcement has on individuals' risk perception will affect social welfare in a manner that is independent of the effect that law enforcement has on social welfare through the manipulation of incentives (e.g., deterring fraud by increasing law enforcement efforts and thus increasing the probability of being caught and punished). ${ }^{67}$ If law enforcement reduces the perception gap, this effect will increase social welfare regardless of law enforcement's impact on the actual risk. An example of such a situation is the hypothetical presented earlier in this Article of an AG's law enforcement initiative that reduces the perceived risk of fraud by $99 \%$, when this risk was previously overestimated by a factor of $100 .{ }^{68}$ As calculated above, ${ }^{69}$ under the assumptions of the hypothetical, the perception gap was reduced by $99.1 \%$.

Conversely, if law enforcement's effect on risk perception causes the perception gap to grow (e.g., by increasing risk perception when the perception gap is already positive or by reducing risk perception when the perception gap

67 Conspicuous law enforcement will not always affect individuals' risk perception. Because of the confirmation bias described in note 35 above, individuals may interpret ambiguity in the message conveyed by law enforcement as supporting their current risk perception. However, confirmation bias is neither ubiquitous nor absolute, so that conspicuous law enforcement is likely to affect risk perception in many cases.

68 See supra Section I.C.

69 See supra note 58. 
is already negative), this effect will reduce social welfare. To illustrate a situation in which increased law enforcement increases the perception gap, modify the original hypothetical so that (perhaps during a stock market upswing), the public underestimates the risk of fraud (rather than overestimates it, as was in the original hypothetical): the actual risk is $0.01 \%$, but the public perceives the risk to be half of that $(0.005 \%)$. The AG launches another enforcement initiative, and persuades the public that his enforcement initiative will further reduce the risk of fraud by $99 \%$ (the public may be initially amenable to that notion having witnessed the AG's apparent success in the original hypothetical). Under these assumptions, the enforcement initiative will increase the perception gap (perceived risk - actual risk) by $99 \%{ }^{70}$

Thus, law enforcement increases social welfare when it reduces the perception gap, such as when the perception gap is positive and law enforcement reduces risk perception. Law enforcement reduces social welfare when it increases the perception gap, such as when the perception gap is negative and enforcement reduces risk perception. ${ }^{71}$

\section{B. The Effect of Conspicuous Law Enforcement on Risk Perception}

The analysis thus far has assumed that law enforcement reduces individuals' risk perception (or, if perceived ineffective, does not change the risk perception). In the remainder of this Article, I will relax this assumption.

While it may seem intuitive that law enforcement would reduce the perception of the risk it purports to address, it may under some circumstances actually increase risk perception. Conspicuous law enforcement bundles two separate - and opposite-messages. One message is that an event related to the risk has occurred (e.g., a business executive has (allegedly) committed fraud). The other message is that the event and the underlying risk are being addressed by government through the enforcement of the law (e.g., charges have been filed against the executive). If, in a particular instance of conspicuous law enforcement, the former message resonates more than the latter, then conspicuous law enforcement increases risk perception. Conversely, if the latter

70 Prior to the enforcernent initiative, the perception gap was $-0.005 \%(0.005 \%-0.01 \%)$, and after the initiative the perception gap was $-0.00995 \%(0.00005 \%-0.01 \%)$.

71 As an exception to this rule, reduction in the perception gap may not increase social welfare if another bias affects exposure to the risk. For example, an investor may overestimate the prevalence of fraud, but also overestımate her ability to identify companies that are "safe" from fraud. If her risk perception regarding the prevalence of fraud is corrected without affecting her perception regarding her ability to identify "safe" companies, the effect on social welfare will be negative. This exception is a result of too narrow a definition of the risk in which a perception gap exists. The risk of the investor being harmed from fraud was separated to two separate risks: the prevalence of fraud in the market, and the probability that the investor will identify and avoid fraudulent companies. In the example above, only the former risk was corrected. If the risk in which the perception gap occurred is properly defined, then a reduction in the absolute value of the perception gap will increase social welfare, without exception. 
message resonates more than the former, then conspicuous law enforcement reduces risk perception.

Consider a non-legal context in which I experienced a similar bundle of messages: while tending to my lawn, I unexpectedly discovered shards of glass in it and immediately disposed of them. After this experience, do I feel more or less secure walking barefoot on the lawn? On one hand, I received a salient reminder of the risk involved; on the other hand, I addressed this risk, so objectively the amount of glass shards in my lawn has diminished, and with it the likelihood of injury.

Similarly, observing a number of executives in Enron, WorldCom, Tyco, and other companies charged with corporate crimes may cause me to perceive corporate crime to be much more prevalent than I thought before, or to perceive the government to be actively pursuing corporate criminals, making such crime less threatening.

Which of the two messages - the risk or the remedy-prevails in a given case of conspicuous law enforcement is a matter of great importance to the determination of optimal enforcement policy, as I will discuss in the next Section. Given its importance, it is surprising that this question has not received the attention of scholars. The goal of this Article is to highlight the importance of this research question and to develop the implications of the answer to this question for optimal law enforcement policy. Identifying the underlying issue-when conspicuous law enforcement increases risk perception and when it reduces it-requires separate and extensive research (both theoretical and empirical) that is beyond the scope of this Article.

I will therefore continue the analysis in this Article by examining each alternative effect on risk perception separately and assessing its effect on optimal law enforcement policy. The extant literature on optimal enforcement policy views enforcement as a trade-off between enforcement costs and deterrent effects (i.e., the manipulation of potential perpetrators' incentives). It does not consider an additional important feature of law enforcement that affects social welfare-its manipulation of the risk perception of the general (non-perpetrator) population. In the remainder of this Section of the Article, I will address this hitherto ignored third effect of law enforcement. As explained below, taking into account law enforcement's effect on risk perception may significantly shape optimal law enforcement policy. When addressing risk perceptions that fluctuate cyclically, due consideration of perception effects may require the adoption of an uncommon policy: counter-cyclical enforcement of the law.

\section{Optimal Enforcement When Enforcement Reduces Perceived Risk}

When conspicuous law enforcement reduces most individuals' perceived risk, conspicuous law enforcement will usually reduce positive perception gaps 
(increasing social welfare) and increase negative perception gaps (reducing social welfare).

I qualify the first statement (that reducing perceived risk will reduce positive perception gaps) because it is possible, though uncommon, for a reduction in risk perception to increase a perception gap that was previously positive, if the magnitude of the risk reduction is greater than twice the magnitude of the pre-existing perception gap (in absolute value terms)-a situation that can be called "overshooting." For example, suppose that prior to the conspicuous law enforcement, the objective probability of a risk was $2.5 \%$ and the perceived probability of the risk was $3 \%$, so the perception gap was $0.5 \%$ (3\%-2.5\%). Assume also that the conspicuous law enforcement reduced the perceived risk by half, to $1.5 \%$, causing the perception gap to become $-1 \%$ $(1.5 \%-2.5 \%)$. The absolute value of the perception gap (and thus the magnitude of the distortion caused by the misperception) has increased from $0.5 \%$ to $1 \%$, thus reducing social welfare. The reason was that the reduction in perceived risk was so great that it "overshot" the pre-existing perception gap, creating the opposite misperception (underestimation of the risk, rather than the prior overestimation of the risk) at a greater magnitude that it was before.

As I argued above, such situations are likely uncommon because the incentives for bias arbitrage decline as the perception gap narrows and become negative when the arbitrageur's actions (e.g., conspicuous law enforcement) increases the perception gap: the AG is seen to address a risk that the public (over-optimistically) views as not severe and thus does not even receive full credit for the objective effects of enforcement on the risk. ${ }^{72}$ Therefore, the AG is likely to stop the law enforcement initiative before the perception gap reverses and to seek more fertile ground for law enforcement (in the form of other risks that have a large positive perception gap).

When describing bias arbitrage in the previous Section, ${ }^{73}$ I explained why AGs (broadly defined to include all individuals who control the enforcement of law) have an incentive to enforce law conspicuously (and thus engage in bias arbitrage) when there is a large positive perception gap (i.e., people significantly overestimate the risk) and refrain from conspicuous enforcement of a risk that has a negative perception gap (i.e., people underestimate the risk). If law enforcement reduces the perceived risk, then the AG's incentives are aligned with the correct policy. When there is a positive perception gap (perceived risk $>$ actual risk), conspicuous law enforcement reduces the perceived risk and therefore the perception gap. When there is a negative perception gap (perceived risk < actual risk), conspicuous law enforcement would exacerbate it by further reducing the perceived risk. In the latter case, it

72 For example, if the actual risk of fraud is $1 \%$ but the public believes the risk is only $0.5 \%$, the $A G$ would receive no credit for a law enforcement initiative that reduced the actual risk by half, to $0.5 \%$, because the public already perceived the risk to be that low.

73 See supra Section I.C. 
is good that the AG does not have an incentive to engage in conspicuous law enforcement.

This does not mean that conspicuous law enforcement is always a good thing when there is a positive perception gap (and when enforcement reduces risk perception): law enforcement has costs (expenses of the prosecutors and the judicial system, costs borne by private parties in order to comply with the law as enforced, costs of error, etc.). These costs may outweigh both the benefits of deterring wrongdoing and the benefits of reducing the public's perception gap.

Nonetheless, law enforcement's benefits from reducing perception gaps are a significant part of the cost-benefit calculus and may tip the scales in favor of law enforcement that, absent these benefits, would not be cost-effective. Importantly, when law enforcement reduces the perceived risk, the incentives of those who control law enforcement are aligned with those of the public in choosing a level of law enforcement that optimizes effects on risk perception.

\section{Optimal Enforcement When Enforcement Increases Perceived Risk}

How does optimal enforcement policy change when conspicuous law enforcement increases, rather than reduces, perceived risk? Unsurprisingly, the effects are the inverse of those described in the previous Section. Social welfare is increased by conspicuous law enforcement (by reducing the perception gap) if the perception gap was previously negative. In other words, if people underestimated the risk, and conspicuous law enforcement increases their risk perception, it will usually cause them to perceive the risk more accurately. ${ }^{74}$

Conversely, conspicuous law enforcement would reduce social welfare (by increasing the perception gap) if previously the perception gap was positive (or there was no perception gap). Put differently, if people overestimated the risk even before the conspicuous law enforcement, and that enforcement initiative further increased their risk perception, then following the initiative they will perceive the risk less accurately than before.

Applied to the context of corporate fraud discussed in Part I of this Article, if enforcement increases risk perception, then anti-fraud enforcement efforts should increase during stock market upswings, in order to curb cognitive biases that cause the public to underestimate the risk of fraud; and anti-fraud enforcement efforts should be reduced during stock market slumps, to avoid exacerbating the public's already excessive perception of the risk of fraud.

Unfortunately, the incentives of the AGs are diametrically opposed. As explained in Section I.C, they benefit from increasing conspicuous law enforcement when there is a positive perception gap (i.e., people overestimate

74 Again this conclusion is qualified because of the possibility of "overshooting," explained in Section II.C. As explained above, AGs have incentıves to avoid "overshooting," making such occurrences uncommon. 
the risk of fraud), and they have a disincentive to address the risk of fraud when there is a negative perception gap (i.e., people underestimate the risk).

As I mentioned in Section II.A, one response to an increase in the perceived risk is efforts to influence others-particularly government-to take actions to reduce the risk. Such influence may involve active lobbying, or passively voting for politicians who emphasize their commitment to address the risk. Both actively and passively, an increase in risk perception and in this response to it will boost politicians' incentives to increase conspicuous law enforcement and thus engage in bias arbitrage.

However, when conspicuous law enforcement increases risk perception, this response to risk leads to a vicious cycle: a positive perception gap (overestimation of the risk) leads to excessive pressure by individuals that government address the risk of fraud. Entrepreneurial prosecutors respond with conspicuous law enforcement. The barrage of enforcement further increases the public's perceived risk, and the public therefore further increases its pressure on government to do more against the seemingly growing risk. Entrepreneurial prosecutors respond with more conspicuous law enforcement, which increases yet again the perceived risk, and with it the pressure on government to do more.

This vicious cycle is not a perpetuum mobile ${ }^{76}$ of course. Eventually the cycle will break by a change in some of the conditions creating it. For example, the stock market's downward trend will reverse, causing a gradual reversal in the perceived risk of fraud, which would reduce pressure on (and incentives for) prosecutors to engage in conspicuous law enforcement. While this vicious cycle persists, however, social welfare continues to decline as individuals excessively self-police, induce government to address the risk, and altogether avoid activities that expose them to the risk. A counter-cyclical enforcement policy that increases conspicuous enforcement during market upswings and reduces conspicuous enforcement during market downturns will avoid this loss to social welfare. But, for the reasons described above, such a policy is contrary to prosecutors' incentives and is therefore unlikely to be implemented, unless the prosecutors operate in an institution that is insulated from the incentives that induce them to enforce cyclically.

75 As with other cognitive biases, the public is unlikely to realize the cause of the bias. In other words, individuals are unlikely to recognize that it is the conspicuous law enforcement that makes them perceive the risk to have increased. Therefore, the public does not punish the prosecutors for the conspicuous law enforcement, but rather urges them to do so in the hope that the law enforcement will reduce the risk. Increased perception of risk is likely to be seen to happen despite-rather than because-of the AG's efforts. If the perception of increased risk persists, however, the public may eventually determine that the AG has "failed" Therefore, bias arbitrage is less attractive to the AG when law enforcement increases risk perception than when it reduces risk perception. But even when law enforcement increases risk perception, bias arbitrage may be more attractive than addressing other risks that have no perception gaps (or negative perception gaps).

76 Latin for "perpetual motion," this term refers to a condition in which an object continues to move indefinitely without being driven by an external source of energy. See Wikipedia, Perpetual Motion, http://en.wikıpedıa.org/wiki/Perpetual_motion. 
In the final Part of this Article, I will examine what structural designs can create this insulation and induce prosecutors to enforce counter-cyclically when such a policy is socially optimal.

\section{Overcoming Impediments to Counter-Cyclical Enforcement}

\section{A. Lessons from (Counter-Cyclical) Monetary Policy}

Counter-cyclical government policies exist in a multitude of areas, such as monetary policy, ${ }^{77}$ fiscal policy, ${ }^{78}$ banking regulation, employment in the public sector, ${ }^{79}$ and tax policy regarding private "stabilization funds." 80

For example, a counter-cyclical fiscal policy requires that a government maintain a budget surplus ("saving" some of its revenue) during years in which its revenues are high and use these funds to cover budget deficits during years in which its revenues are low. If successful, such a policy would allow the government to maintain a steady level of expenditure despite volatility in its revenues. This is particularly important to governments whose revenues are undiversified and cyclical, such as revenues from the sale of commodities. An illustration of such a policy is the Iranian government's Oil Stabilization Fund,

77 The counter-cyclical policy in this context involves restricting the money supply (e.g., by raising interest rates) when the economy is expanding rapidly and expanding the money supply (e.g., by reducing interest rates) when the economy is contracting. See, e.g., PETER BOFINGER, MONETARY POLICY: GOALS, INSTITUTIONS, STRATEGIES, AND INSTRUMENTS (2001).

78 The counter-cyclical policy in this context is restricting spending (i.e., creating a budget surplus) when government revenues are high, and expanding spending (1.e., creating a budget deficit) when government revenues are low. See, e g., Richard Lapper \& Benedict Mander, Chile Refuses to Be Swayed by Volatility in Price of Copper, FIN. TIMES, Dec. 12, 2006, at 4 (describıng a counter-cyclical policy Chtle's finance minister created in 2000 , under which the government is forced to create a budget surplus when copper prices are high, and is allowed to spend at a deficit tied to copper prices when they are low); Gareth Smyth, Iranian President Under Budget Pressure, Fin. Times, Mar. 2, 2006, at 8 (describing Iran's Oll Stabilization Fund, in which the government must place all revenues from oll above a certain price, and which the govemment uses to fund budget deficits when oil prices are low); see also Bradley M. Braun \& Yasuji Otsuka, Case Study: Desıgning State Contingency Funds as a Markov Process, 14 MANAGERIAL \& DECISION ECON. 277, 277 (1993) (“[B]oth politicians and economists have been exploring options for dealing with inflexible budget rules. The most popular solution has been the contingency fund [or rainy day fund], which prescribes that monies be set aside during a good economic period to be made available in the future when adverse economic conditions occur.")

79 The counter-cyclical policy in this context (which is closely tied to, and is often an implementation of, counter-cyclical fiscal policy) involves increasing employment in the public sector when the economy is contracting and reducing employment in the public sector when the economy is expanding. See, e.g., Bertil Holmlund, Central Wage Setting, Wage Drift and Stabilization Policies Under Trade Unionism, 38 OXFORD ECON. PAPERS 243, 257 (1986).

80 The counter-cyclical policy in this context involves the government permitting private firms to deduct from their taxable income a certain amount which is kept as a "stabilization fund," to be used by the firm during recession. In this case, government is subsidizing through a tax break countercyclical policies implemented by private firms. See, e g., John B. Taylor, The Swedish Investment Funds System as a Stabilization Policy Rule, 1982 BROOKINGS PAPERS ON ECON. ACTIVITY 57 (describing Swedish tax policy during the 1950 s and 1960 s, which gave tax benefits to firms that placed some of their profits in a stabilization fund, which the firms were allowed to use during periods of recession). 
into which the government allocates oil revenues in excess of a certain oil price threshold (presumably, oil revenues below that threshold are included in the regular budget). ${ }^{81}$ This fund is then intended to be used for long-term infrastructure projects and to cover budget deficits in years in which oil prices drop below the threshold price. ${ }^{82}$

To be effective, counter-cyclical policies require discipline at all stages of the cycle. However, the actions they require are usually unpopular at least at one point in the cycle. In the case of counter-cyclical fiscal policy, it is difficult for the government to curtail its spending when revenues are high and it has the means to spend. As it becomes obvious that funds are available, pressure mounts to make use of the money and reap short-term benefits. Indeed, in the Iranian Stabilization Fund example, there are reports that the government diverted money from the fund to the general budget while oil prices were high, ${ }^{83}$ and increased the threshold oil price so that more oil revenue was diverted to the budget and away from the fund. ${ }^{84}$

Counter-cyclical fiscal policies are prone to such failure because they tend to be administered by politicians who are susceptible to short-term political pressures. Some counter-cyclical policies have demonstrated greater discipline, such as monetary policy implemented by central banks.

Monetary policy involves the manipulation of the supply of money to affect the level of economic activity. ${ }^{85}$ Central banks have various tools that allow them to affect (raise or lower) interest rates, and through them the supply of money. ${ }^{86}$ Excessively restricting the money supply hinders economic activity, while excessively increasing the money supply causes inflation. To execute its role in maintaining price stability, the central bank needs to act counter-cyclically: increase interest rates to constrain the money supply when it becomes excessive (which occurs when an economy is rapidly expanding and "overheating") and reduce interest rates to expand the money supply when it is insufficient (which occurs when the economy experiences a contraction). As one central banker illustrated, the job of the Federal Reserve Bank is to "take away the punch bowl just when the party gets going." 87

Just as restraint from spending is the Achilles' Heel of counter-cyclical fiscal policies, so it is with the decision to reduce the money supply (i.e.,

81 See Smyth, supra note 78.

82 Bill Spindle, Behind Rise of Iran's President: A Populist Economic Agenda, WaLL ST. J., June 22, 2006, at A1.

83 See id.

84 Smyth, supra note 78.

85 The following is a very simplified explanation of monetary policy and the central bank's role in determining and implementing it. For a more detailed discussion see BOFINGER, supra note 77.

86 For more on the tools used by the U.S. Federal Reserve Bank to implement monetary policy, see Cheryl L. Edwards, Open Market Operations in the 1990s, 83 FED. RES. BuLL. 859 (1997).

87 This quote is attributed to William McChesney Martin, who was Chairman of the Board of Governors of the Federal Reserve between 1951 and 1970. See 3 JeRRY W. MARKHAM, A FinANCIAL HISTORY OF THE UNITED STATES 3 (2002). 
raising interest rates is likely to be an unpopular action in the short term). Raising interest rates increases the cost of capital for businesses, reducing their profits, and making some previously profitable activities unprofitable. Investors suffer as both stock and bond prices decline. The gains from raising interest rates are in the long term, and are often invisible - the avoidance of an inflationary cycle that would have occurred if the money supply was left unchecked. Yet in recent years, central banks in many countries have done an adequate and perhaps even admirable job of resisting political pressures and executing unpopular policies that maintained inflation at low levels. ${ }^{88}$ What features endow central banks with the institutional backbone to resist political pressures and maintain the course of a counter-cyclical policy?

The literature on central bank independence identifies three elements that insulate central banks from political pressure: ${ }^{89}$ (a) Goal independence-the freedom of the bank to determine the balance between price stability, unemployment and growth in setting its objectives; (b) Instrument independence-the ability to execute its policies without interference (which requires limiting or delegating to the central bank those governmental powers that can thwart the central bank's actions-such as control of short-term interest rates, control of exchange rates, or restrictions on central bank credits to the government); (c) Personal independence-reducing political actors' power over the appointment and removal of members of the central bank governing body.

In the following Section I will consider how these elements may be adapted to counter-cyclical anti-fraud enforcement.

\section{B. Institutional Designs that Facilitate Optimal Enforcement}

Implementing each of the three elements of independence mentioned above in the context of anti-fraud law enforcement faces significant challenges.

\section{Goal Independence}

Central banks must balance between price stability (i.e., prevention of inflation), unemployment, and growth. In the long term, there is no trade-off between these factors. As Nobel Prize laureates Milton Friedman and Edmund

88 Even now, central banks are not entirely free of political influence, as politicians vocally opine on monetary policy (and perhaps pressure central banks in other ways that are less visible), and central bankers make efforts to build not only market credibility, but also political capital. See, e.g., Krishna Guha, Bernanke's Style Builds Polttical Capital, FIN. TIMES, Feb. 16, 2007, at 6 (describing the U.S. Federal Reserve Bank Chairman's successful efforts in maintaining a good relationship with Congress and the importance this has in facilitating changes in the Fed's decision-making process). Notwithstanding the lack of perfect insulation, central banks are relatively independent of political influence compared to corporate crime prosecutors. It is hard to imagine a position in the central bank catapulting one into becoming a governor or a president.

89 See BOFINGER, supra note 77, at 210-16; Vittorio Grilli et al., Political and Monetary Institutions and Public Financial Policies in the Industrial Countries, 6 ECON. POL'Y 342, 366 (1991). 
Phelps demonstrated, the public adjusts its expectations of inflation, so that in the long run more inflation does not allow for more growth or less unemployment. ${ }^{90}$ In the short run, however, reducing the money supply by raising interest rates may reduce growth and increase unemployment.

A similar situation occurs with the enforcement of anti-fraud laws. In the long run, the public will correct its perception gaps. It will do so more quickly if the law enforcer does not exacerbate a positive perception gap through conspicuous law enforcement and if the law enforcer does increase risk perception when there is a negative perception gap.

In the short term, however, a public with a positive perception gap would demand that immediate action be taken to address the (overestimated) risk, and a public with a negative perception gap may be outraged by conspicuous enforcement of anti-fraud laws that brings a stock market surge to a halt. Thus, when conspicuous law enforcement increases risk perception, implementing the correct long-term policy will cause fear and anger among the public in the short term. Nonetheless, if the goal of anti-fraud laws is to maximize long term efficiency, the public's immediate sentiments should not be a consideration for abandoning the optimal long-term policy. In fact, the law enforcer should be shielded from precisely these short-term pressures.

Counter-cyclical anti-fraud law enforcement does face, however, a potential trade-off between the law's effect on potential perpetrators' incentives and the law's effect on the general population's perceptions. As we mentioned above, a counter-cyclical policy would advocate reducing conspicuous law enforcement when the public has a positive perception gap, to avoid exacerbating their already excessive perception of the risk. Refraining from enforcing the law, however, would reduce the deterrent effect on potential perpetrators, possibly increasing the amount of fraud committed. Similarly, the counter-cyclical policy endorses an increase in conspicuous law enforcement when the public has a negative perception gap, to remedy the public's underestimation of the risk. However, increased enforcement will also increase deterrence of potential perpetrators, perhaps excessively so. Thus, a three-way trade-off exists between enforcement costs, enforcement's effects on the incentives of potential perpetrators, and enforcement's effects on the perceptions of the general public.

In addition to balancing between the three considerations that are affected by law enforcement (cost, effect on incentives, effect on perception), a law enforcer seeking to implement an efficient counter-cyclical policy is plagued by the absence of a developed theoretical basis and of developed techniques to collect relevant empirical data (such as data shedding light on the public's risk

90 See, e.g., Milton Friedman, The Role of Monetary Pollcy, 58 AM. ECON. REv. 1, 10 (1968) (" $[\mathrm{T}]$ he simultaneous fall ex post in real wages ... is what enabled employment to increase. But the decline ex post in real wages will soon come to affect anticipations. Employees will start to reckon on rising prices of the things they buy and to demand higher nominal wages for the future."). 
perception and changes to it). The study of cognitive biases is in its infancy and has not yet been developed to the extent that macroeconomics has. ${ }^{91}$

One question that is of great importance to the law enforcer in crafting the optimal enforcement policy is whether, in the particular circumstances, conspicuous law enforcement increases or reduces risk perception. As explained in Part II of this Article, if conspicuous law enforcement reduces risk perception, then the law enforcer's incentives are aligned with optimal enforcement policy. In these situations, the current system of prosecution may be adequate. However, when law enforcement increases risk perception, optimal enforcement policy would be counter-cyclical, and law enforcement should be placed in the hands of enforcers who are insulated from political pressure. We need, therefore, to improve our understanding of how individuals interpret the bundled message in conspicuous law enforcement and when it increases (and when it reduces) their risk perception.

Another area in which further research would dramatically improve the effectiveness of counter-cyclical enforcement policy is the assessment of the public's risk perception, ideally allowing an estimate of the direction (positive or negative) and magnitude of the public's perception gap. Again, monetary policy has faced a similar challenge in collecting reliable data that serve as good proxies for relevant criteria. For example, the measurement of the money supply (which is crucial in determining monetary policy) has been extensively debated and modified several times. ${ }^{92}$ And again, monetary policy is years ahead of the developmental stage in which the assessment of risk perception is.

Theories on cognitive biases give some evidence as to which situations lead to which kind of biases. It is very probable that over time these theories will improve in sophistication and in nuance, including the ability to predict well the effects of an interaction of multiple biases. As for empirical measurements of risk perception, measurements based on surveys suffer from subjectivity. One can measure the outputs of increased risk perception (in the case of fraud: increased self-policing, increased pressure on government and others to address the fraud and increased avoidance of activities exposing one to fraud). However, some of these are hard to observe. One of the easier activities to observe is changes in avoidance of activities, which, in the case of fraud, mostly has to do with investing in capital markets. However, a reduction

91 Even macroeconomics has not yet developed into an exact science. The crafting of monetary policy is still seen by many to be as much art as it is science. See, e.g., Olivier Blanchard, Monetary Policy; Science or Art?, Panel Discussion at "Monetary Policy: A Journey from Theory to Practice" Colloquium (April 2006), available at http://econ-www.mit.edu/files/742 ("[M]onetary policy is much closer to science than it was [twenty years ago]. But it is still very far from science."). The study of cognitive biases for the purpose of devising optımal law enforcement policies is many steps less advanced, though one can hope it will develop with time to be as useful a guide to the law enforcer as macroeconomics is to the central banker.

92 See, e.g., Ulnke Dennig, Problems of Measuring Money Supply in the Euro Area, 33 INTERECONOMICS 299 (1998) (discussing the lack of a measurement standard for the euro area money supply just before responsibility for monetary policy was transferred to the European Central Bank in 1998) 
in such investments, while possibly a result of heightened risk perception, may also be a result of changes in the relative costs or effectiveness of the alternative responses to the risk. For example, an individual's risk perception may have increased, but at the same time the individual anticipates that the costs of self-policing (or influencing the government to intervene) have declined, making them more attractive than avoiding the risk, and therefore displacing risk avoidance in the individual's mix of responses. One can predict that, as with any area to which human ingenuity is applied, better measurement techniques and better proxies would form if there were a demand for them. This demand should come, in part, from counter-cyclical law enforcers.

\section{Instrument Independence}

Independence to set a counter-cyclical law enforcement policy is meaningless if others, who are not isolated from political pressures and therefore have an incentive to endorse cyclical enforcement, have the ability to thwart the law enforcer. This problem is acute in the case of manipulating the public's risk perceptions, since so many individuals and entities can and do engage in such activities. First of all, there is a multitude of government actors whose actions affect the perception of fraud. Witness the aftermath of the recent financial scandals, in which the SEC, multiple federal district attorneys, and multiple state attorneys general actively competed over the spotlight for charges they pressed against alleged wrongdoers.

The simplest way to curb this competition is to allocate all prosecutorial authority in the hands of a single entity (say, the SEC), insulate that entity to the best extent possible from political pressure, and preempt other government bodies from taking actions that would have a severe impact on the public's perception of the risk of corporate fraud. A more moderate reform would leave the multitude of prosecutors with their existing powers, but require them to receive approval to file their charges from a single, politically insulated entity that will serve as an "expert grand jury." Though this reform is less dramatic, I am skeptical about its effectiveness because prosecutors can generate the perception effects of conspicuous law enforcement simply by (very publicly) filing charges with the "expert grand jury." Even if those charges would be dismissed, the prosecutor may receive the private benefits of public attention for her devotion to fighting fraud (just as the public may be more aware of a prosecutor's very public announcement of the filing of charges and of conspicuous "perp walks" than of the ultimate outcome of the trial, which the prosecutor might not publicize if she lost).

A law enforcer may be thwarted not only by the actions of other government entities, but also by the actions of private entities. For example, the media has a very significant role in shaping risk perceptions. ${ }^{93}$ Private firms 
that actively operate in capital markets have an effect on changes in market prices and on the resulting perception of relevant risks. Preventing them from acting and expressing views that trigger cognitive biases and manipulate perceptions would likely run afoul of the First Amendment. Thus, the law enforcer has to live with some interference from private parties. In this, she is not alone. The central banker, too, does not have unfettered control of the market behavior. In one case, for example, a central bank's policies were challenged by speculators who took market positions adverse to the bank's policies, and in some cases the speculators won, causing the central bank to lose billions in an (ultimately futile) attempt to enforce its policy. ${ }^{94}$

But central banks have some degree of control over these private actors through their credibility. Their policy serves as a focal point, and as long as they have the market's confidence, they control the private actors by "dividing and conquering"- each private actor normally does not have enough financial power to undermine the central bank's position on its own, and if the central bank has credibility, each private actor is likely to expect that other actors would not challenge the bank's policy, making it too risky for that actor to challenge the bank. As The Economist describes it:

Central banks have become more open largely because of a change in the way monetary policy is thought to work. The old view of it was rather mechanical ... . Now policy is thought to operate mainly through expectations. Central banks see the setting of today's interest rates as part of a wider task: giving markets, consumers and firms reason to expect that future rates will keep inflation in bounds. If they believe inflation will stay at, say, $2 \%$ or so, they will act accordingly and thus help to hold it near the mark. ${ }^{5}$

An expert corporate crime agency may earn the same respect and exert the same influence on private parties' expectations. For example, lawyers contemplating private lawsuits against a company may refrain from doing so when the agency expresses its view that public action against the company is inappropriate and that the perception of fraud is, in this case, exaggerated. The lawyers would do so not necessarily out of respect to the agency, but out of recognition that others (including the judge and jury in their case) would be influenced by the agency's position, reducing the lawyers' likelihood of success. The same influence can be exerted in the opposite direction, inducing lawyers to file private lawsuits when the agency signals through its actions that greater concern for fraud is in order. ${ }^{96}$

94 See Daniel Dombey, The Billion-Dollar Memory Lapse: George Soros Has Moved on to Higher Things Since Black Wednesday 1992. When He Broke the Bank of England and Made a Fortune-or Was lt a Thursday?, Fin. TIMES, Aug. 5, 2006, at 14 (interviewing Soros nearly twenty-five years after he "made [one billion dollars] in a day by betting against the Bank of England").

95 The Oracle Becomes Less Oracular, ECONOMIST, Dec. 2, 2006, at 80.

96 See Howard M. Erichson, Coattail Class Actions: Reflections on Microsoft, Tobacco, and the Mixing of Public and Private Lawyering in Mass Litigation, 34 U.C. DAVIS L. REV. 1, 2 (2000) ("In each case, government lawsuits broke down the barriers to successful litigation, and private litigants, particularly those pursuing class actions, rode the government's coattails."). 


\section{Personal Independence}

Central banks enjoy a degree of personal independence through features that shield decision makers from political influence that affects their present or future personal well-being (e.g., the ability of a politician to fire a central banker who is not beholden to her, or the central banker's temptation of desirable future employment that would emerge only if he yields to certain political interests). In contrast to central bankers, many of the prosecutors who enforce corporate crime laws (and therefore have an effect on the perception of the risk of fraud) are in positions that are extremely susceptible to political pressure. Some even use a conspicuous "corporate busting" record as a prosecutor to launch political careers. ${ }^{97}$ This vulnerability to political pressures makes them unlikely to sustain a counter-cyclical enforcement policy when it is needed.

Structural safeguards protect certain government actors such as judges and central bank board of governors members from political pressures. Such mechanisms include political diversification in the nomination and confirmation processes, staggered terms of office, tenure or term appointments with strict limitations on removal, restrictions on future employment (to prevent the position from being a springboard to a political career), etc. Many of these are easily applicable to a single agency that specializes in countercyclical law enforcement (i.e., enforcing the law in areas in which the public's risk perception fluctuates cyclically and in which conspicuous law enforcement increases risk perception). It would likely not be possible to extend these safeguards to a large, decentralized group of prosecutors at different governmental levels (federal, state, and local). This is yet another reason to consider investing counter-cyclical law enforcement in the hands of a single entity rather than in the current decentralized structure.

\section{Conclusion}

Optimal law enforcement efforts are often presumed to be constant, fluctuating only when the balance between enforcement costs and deterrence benefits fluctuates due to a change in one of these two factors.

This paper added a third factor that significantly impacts the social welfare effects of law enforcement: the effect of law enforcement on the public's perception of the risk the law purports to address. This expansion of the optimal enforcement model allowed me to introduce a macroeconomic

97 See Jenny Anderson, About Those Fears of Wall Street's Decline, N.Y. Times, Jan. 26, 2007, at C6 (reporting on Eliot Spitzer, "the enforcer turned laissez-faire governor" of New York who "not long ago was a prosecutor blazing through Wall Street's boardrooms"); Weston Kosova, Keeping a Close Eye on Wall Street, NEwSWEEK, Dec. 29, 2003, at 94, avallable at http://www.msnbc.msn.com/ id/3770497/site/newsweek/ (reporting on Spitzer's "crusade to expose Wall Street's grimy side ... [or] Wall Street war [that] made him one of the most envied politicians in the country"). 
element to the microeconomic analysis of optimal law enforcement-the cyclical fluctuation of the public's risk perception. Introducing this cyclical element highlighted the importance of a currently neglected question: under what circumstances does conspicuous law enforcement reduce risk perception, and when does it increase risk perception? This determines the optimal enforcement policy: a cyclical policy when law enforcement reduces risk perception and a counter-cyclical policy when law enforcement increases risk perception.

Anti-fraud corporate and securities laws seem to be enforced cyclically. I suggest that this trend is connected with the cyclical fluctuation in the public's risk perception, because through law enforcement the agencies engage in bias arbitrage that yields private profits. Thus, law enforcers have an incentive to enforce anti-fraud laws cyclically, which is likely the optimal policy when conspicuous law enforcement reduces risk perception.

But when conspicuous law enforcement increases risk perception, a counter-cyclical policy is more efficient. Yet law enforcers still face the same incentives to enforce law cyclically. In the final part of this paper, I examined existing counter-cyclical government policies (in particular, monetary policy implemented by a central bank) to determine what elements insulate law enforcers from the perverse incentives to enforce cyclically, and I suggested how these elements could be applied in the context of enforcing corporate antifraud laws.

This Article highlights the importance of empirical and experimental research that will identify when law enforcement increases risk perception and when it reduces it. It creates the framework for an application-countercyclical enforcement of corporate and securities laws-the effectiveness of which depends on the quality of our understanding of the effect of law enforcement on risk perception. In effect, this Article creates a "prize" to induce scholars to explore this question and to reward those who improve our understanding of the relationship between law and risk perception. As such understanding develops, law enforcement will be better able to manage an important effect of law enforcement that is largely neglected in the extant literature on optimal law enforcement: law enforcement's effect on the risk perception of potential victims. This Article takes the first steps in envisioning what structural reforms would be desirable in our law enforcement institutions in order to efficiently manage these perception effects. 
